\title{
Integrated analysis of water quality from two rivers used for public supply in southern Brazil
}

\author{
Análise integrada da qualidade da água de dois rios utilizados para o abastecimento \\ público no sul do Brasil
}

Flávia Bernardo Chagas ${ }^{1}$, Camila Fátima Rutkoski ${ }^{1}$, Gregori Betiato Bieniek ${ }^{1}$,

Gean Delise Leal Pasquali Vargas ${ }^{1}$, Paulo Afonso Hartmann ${ }^{1 *}$ and Marília Teresinha Hartmann ${ }^{1}$

\author{
${ }^{1}$ Laboratório de Ecologia e Conservação, Universidade Federal da Fronteira Sul - UFFS, \\ Rodovia ERS 135, Km 72, 200, CEP 99700-970, Erechim, RS, Brazil \\ *e-mail: hartmann.paulo@gmail.com
}

Cite as: Chagas, F.B. et al. Integrated analysis of water quality from two rivers used for public supply in southern Brazil. Acta Limnologica Brasiliensia, 2017, vol. 29, e14.

\begin{abstract}
Aim: This study aimed to evaluate the water quality of streams that are used for public supply, through an integrated analysis using a biotic index, as well as physicochemical and microbiological parameters. Methods: The data were obtained monthly, from November 2014 to April 2015, at eight locations in two rivers in the south of Brazil. The landscape is predominantly rural, with the occurrence of small reforested areas, as well as yerba mate and grape cultivations. Macroinvertebrate samples were collected monthly using a Surber sampler. Water temperature and dissolved oxygen concentration were measured in the field using a portable oximeter. The following parameters were measured in the laboratory: $\mathrm{pH}$, Turbidity, BOD, Conductivity and Nitrate. Results: The evaluation carried out in the rivers revealed good water quality, but some sample sites presented reduced water quality. The waters of the Leâozinho River were classified as doubtful at site 1 and as good at sites 2, 3 and 4. Ligeirinho River presented an acceptable rating at sites 1 and 4 and was classified as good at sites 2 and 3 . The BMWP' index was significantly correlated with the abundance of macroinvertebrates, EPT richness and BOD. The abundance and richness of macroinvertebrates in Leãozinho and Ligeirinho Rivers were associated with the physical, chemical and microbiological parameters. Conclusion: This study reinforces the importance of biomonitoring in the evaluation of water quality for human consumption, considering that environmental management and monitoring practices should integrate physicochemical, microbiological and biological parameters.
\end{abstract}

Keywords: macroinvertebrates; BMWP' index; physicochemical parameters; human consumption.

Resumo: Objetivo: O objetivo deste estudo foi avaliar a qualidade da água de dois rios usados para abastecimento público por meio de análise integrada utilizando um indicador biótico, além de parâmetros físico-químicos e microbiológicos. Métodos: Os dados foram coletados mensalmente de novembro de 2014 a abril de 2015 em oito pontos distribuídos nos dois rios analisados. A paisagem no entorno dos rios é essencialmente rural, com pequenas áreas de reflorestamento e áreas de cultivo agrícola. Os macroinvertebrados foram coletados usando amostrador do tipo "Surber". A temperatura da água e a concentração de oxigênio dissolvido foram medidos em campo utilizando oxímetro portátil. Os seguintes parâmetros foram analisados em laboratório: $\mathrm{pH}$, turbidez, $\mathrm{DBO}$, condutividade e nitrato. Resultados: A avaliação mostrou qualidade da água boa, mas alguns pontos amostrais mostram decréscimo na qualidade da água. A água do Rio Leãozinho foi classificada como duvidosa no ponto 1 e boa nos pontos 2, 3 e 4. No Rio Ligeirinho, a água foi classificada como aceitável nos pontos 2 e 4 e boa nos pontos 2 e 3 . O índice BMWP' mostrou correlação com a abundância de 
organismos, riqueza de EPT e DBO. A abundância e riqueza de macroinvertebrados nos dois rios foram associadas com parâmetros físicos, químicos e microbiológicos. Conclusóes: Este estudo reforça a importância de biomonitoramento na avaliaçáo da qualidade da água para consumo humano, considerando que gestão ambiental e práticas de monitoramento devem ser integradas com parâmetros físico-químicos, microbiológicos e biológicos.

Palavras-chave: macroinvertebrados; índice BMWP'; parâmetros físico-químicos; consumo humano.

\section{Introduction}

Cities are places with many social, economic and environmental problems, especially in developing countries, where social disparities and the lack of financial and technical resources for matching urban infrastructure and environmental management issues are greater (Gorski, 2010). One of the main challenges for Brazilian municipalities is the management of water quality for public supply. The main sources of degradation of freshwater resources in Brazil are domestic and industrial sewage, released into continental waterbodies with little or no treatment, resulting in environmental and sanitary degradation of rivers (Esteves, 1998). This type of pollution affects the physical, chemical and biological characteristics of the water and the soil and can affect the health, survival and behavior of biological communities dependent on the water basin (Esteves, 1998; Goulart \& Callisto, 2003).

Analysis of water pollution caused by human activities should involve an integrated approach that monitors the physical, chemical and biological quality of the water (Goulart \& Callisto, 2003). Biomonitoring of aquatic environments can be carried out through the use of living organisms, enabling the evaluation of changes in the environment (Buss et al., 2003; Callisto \& Moreno, 2004). Benthic macroinvertebrates, that live part of their life cycle associated with aquatic ecosystems and represent the ecological conditions of the environment in which they live, are used for analysis of rivers (Costa et al., 2006; Teive et al., 2008).

These organisms are sensitive to habitat changes and respond to them (Lima, 2000). The presence or absence of certain macroinvertebrate families serves as an indicator of the water quality status (Straskraba \& Tundisi, 2000) and may indicate both recent or medium-term impact (Metcalfe, 1989). The advantages of biomonitoring with macroinvertebrates are the ease of collection and identification of the species, as well as the fact that they are associated with the sediment and have low mobility. Several studies have demonstrated the potential of these organisms in biomonitoring river basins used for public water supply as a function of different land use and occupation (Buss et al., 2003; Callisto \& Moreno, 2004; Corgosinho et al., 2004; Hepp \& Restello, 2007; Monteiro et al., 2008; Barbola et al., 2011).

According to data from the Brazilian Institute of Geography and Statistics (IBGE) obtained from the 2010 Census, medium-sized cities (with populations between 100,000 and 500,000 inhabitants) are the fastest growing in the country, representing a large number of Brazilian cities, as is the case in the present study area (IBGE, 2014). These growing urban areas need to protect and plan for an increasing demand for water supply and treatment (e.g., Goonetileke et al., 2014). Understanding the water quality status of rivers supplying these cities can provide parameters for decision-making in other cities of similar size and status. This study aimed to evaluate the water quality of two southern Brazilian rivers used for public supply through the use of the biotic index BMWP' and assessment of physical, chemical and microbiological parameters.

\section{Material and Methods}

\subsection{Study area}

The study was carried out in two rivers used for public supply in the city of Erechim, located in the north of the state of Rio Grande do Sul. The Leãozinho and Ligeirinho Rivers are tributaries of the Tigre River and part of the drainage area of the Area de Proteçáo Ambiental dos rios Ligeirinho e Leãozinho (APA) (27039'38.3" to 27042'48.6" S; $52^{\circ} 14^{\prime} 15^{\prime \prime}$ to $\left.52^{\circ} 17^{\prime} 23^{\prime \prime} \mathrm{W}\right)$. The APA drainage area has several smaller tributaries, occupying 39,496 kilometers in extension with an area of 32.21 hectares. The main source of water for the city (reservoir of the Companhia Riograndense de Saneamento - CORSAN) is located at the confluence of these two rivers, in the Ligeirinho management unit. The landscape is predominantly rural, with the occurrence of small reforested areas, as well as yerba mate and grape cultivations (Theodoro \& Decian, 2014). The land use in the vicinity of the rivers is characterized by agriculture and cattle ranching, as well as scattered dwellings (Theodoro \& Decian, 2014; Hepp et al., 2007; 
König et al., 2008; Hepp et al., 2010; Bernardi, 2014). Riparian forest and other vegetation is either scarce or absent around both rivers (Theodoro \& Decian, 2014).

Four data collection sites were chosen in each of the Leãozinho and Ligeirinho rivers, distributed between the source and the reservoir entrance. Site 1 (ST1) of each river was located near the source; sites 2 and 3 were intermediate; and site 4 was located close to the reservoir.

\subsection{Biological parameters}

Macroinvertebrates were collected once a month at each site from November 2014 to April 2015, using a Surber sampler (mesh of $250 \mu \mathrm{m}$ and area of $0.1 \mathrm{~m}^{2}$ ) (Silveira, 2004). Over six months, 48 samples of benthic macroinvertebrates were collected. The specimens were placed in labeled bottles containing 70\% ethanol and taken to the Laboratory of Ecology and Conservation of the Universidade Federal da Fronteira Sul. The organisms were screened under stereomicroscope with 45x magnification and placed in Petri dishes with water and $70 \%$ ethanol. When possible, the benthic macroinvertebrates were identified to the taxonomic level of family, using the Manual de Identificação de Macroinvertebrados Aquáticos do Estado do Rio de Janeiro (Mugnai et al., 2010).

\subsection{Physicochemical parameters}

Together with the biological collection, an analysis of the water was carried out once a month at each site ( 48 samples of water for physicochemical parameters were collected). Water temperature and dissolved oxygen concentration were measured in the field using a portable oximeter (Alfakit AT 160). Using the collected water samples, the following parameters were measured in the laboratory: $\mathrm{pH}$ (hydrogen potential) using a $\mathrm{pH}$ meter (MS Tecnopon $210 \mathrm{MPa}$ ); Turbidity in NTU (nephelometric unit), using a turbidimeter (Policontrol AF 2000); Biochemical Oxygen Demand (BOD), determined with the Lovibond OxiDirect equipment for reading of dissolved oxygen after five days, with the samples incubated at $20^{\circ} \mathrm{C}$; Conductivity, using a conductivity meter (Gehaka CG 1800) and Nitrate, using the phenoldissulphonic acid technique described in Standard Methods (APHA, 1999).

\subsection{Microbiological parameters}

The samples were collected in a sterile container directly from the rivers, stored and transported under refrigeration to the laboratory. The multiple tubes fermentation technique was used, according to the methodology recommended by Standard Methods (APHA, 1999). The most probable number was determined according to the Most Probable Number (MPN) table, recommended by the Bacteriological Analytical Manual (Andrews et al., 1984).

\subsection{Data analysis}

From the identified benthic organisms, the BMWP' index was calculated, using the adaptation by Alba-Tercedor (1996) and Department of Environment and Water Resources of the state of Paraná (2014). This index arranges the families of aquatic macroinvertebrates into nine groups, following a gradient of increasing tolerance to organic pollution (Loyola, 2000). Each family corresponds to a score, that ranges from 10 to 1 , where families more sensitive to contamination receive the highest scores and the most tolerant, receive the lowest scores.

Values of abundance and taxonomic richness were estimated, and the Shannon Wiener diversity index (Magurran, 2004) was calculated, considering the richness of species in relation to the total number of individuals present at the site. The Shannon Wiener diversity index was calculated for each site in the rivers (ST1-4) and each river (Leãozinho and Ligeirinho river). The classification of the waterbodies by the Shannon Wiener index followed Barbosa et al. (2001) H’ $3.0=$ healthy waterbody; between $1.5 \leq \mathrm{H}^{\prime}<3.0=$ moderately affected environment; and $\leq 1.5$ = water pollution.

The EPT (Ephemeroptera, Plecoptera and Trichoptera) ratio was also used, consisting of the sum of EPT abundance/Total abundance (Reice \& Wohlenberg, 1993). For this study, we calculated the total abundance of EPT, the ratio of EPT (\% EPT) and the EPT richness for each sample site in the rivers.

The results of the physicochemical and microbiological water analyses at the studied sites were compared to resolution \#357 of CONAMA (Brasil, 2005). We used a one-way analysis of variance (ANOVA) and Tukey post hoc test (when $p<0.05)$ to evaluate differences in mean values of macroinvertebrate abundance, taxonomic richness, and $\mathrm{EPT/EPT \% /EPT,} \mathrm{between} \mathrm{rivers} \mathrm{and} \mathrm{among}$ sites, as well as differences in physical, chemical and microbiological parameters among sites. Abiotic parameters were correlated with the results of the BMWP' biotic index through multiple correlations, using the Pearson coefficient. The tests were considered significant at $\mathrm{p} \leq 0.05$. We used Statistica 8.0 (STATSOFT Inc., USA) (Bas \& Boyaci, 2007) 
and, for the calculation of biological indices, we used the DIVES program (Rodrigues, 2015).

\section{Results}

A total of 4096 macroinvertebrates, distributed among 41 taxa of Annelida, Nematoda, Crustacea, Arachnida and Insecta were found, the latter being the most representative group. Leãozinho River had greater macrofaunal abundance, with 2,244 individuals, than Ligeirinho River, with 1,852 individuals (Table 1).
The abundance values showed no significant differences between the rivers $\left(F_{1,46}=0.62, \mathrm{p}=0.43\right)$ and sites $\left(F_{7.40}=0.91, \mathrm{p}=0.50\right)$, but taxonomic richness of organisms was significant for both $\left(F_{1,46}=5.84, \mathrm{p}=0.01\right.$, between rivers; $F_{7,40}=3.96, \mathrm{p}<0.01$, among sites - significant in ST 3, Leãozinho River and ST 2 Ligeirinho River, $\mathrm{p}<0.05$, Tukey test). The values of the Shannon Wiener diversity index were $\mathrm{H}^{\prime}=1.05$ for the Leãozinho River and $\mathrm{H}^{\prime}=1.09$ for the Ligeirinho River (water pollution, according classification of the waterbodies by the Shannon Wiener index).

Table 1. Total number of benthic macroinvertebrates collected in the Leãozinho and Ligeirinho Rivers (Erechim, Rio Grande do Sul), by site (ST1-4), from November 2014 to April 2015.

\begin{tabular}{|c|c|c|c|c|c|c|c|c|}
\hline \multirow{2}{*}{ Taxa } & \multicolumn{4}{|c|}{ Leãozinho River } & \multicolumn{4}{|c|}{ Ligeirinho River } \\
\hline & ST1 & ST2 & ST3 & ST4 & ST1 & ST2 & ST3 & ST4 \\
\hline \multicolumn{9}{|l|}{ Annelida } \\
\hline Oligochaeta & 13 & 5 & 3 & 0 & 0 & 1 & 2 & 0 \\
\hline Nematoda & 0 & 2 & 0 & 0 & 0 & 0 & 0 & 0 \\
\hline \multicolumn{9}{|l|}{ Arthropoda } \\
\hline \multicolumn{9}{|l|}{ Crustacea } \\
\hline Aeglidae & 16 & 10 & 0 & 4 & 3 & 8 & 5 & 2 \\
\hline Hyalellidae & 0 & 0 & 0 & 0 & 1 & 0 & 0 & 0 \\
\hline Talitridae & 6 & 9 & 0 & 0 & 157 & 3 & 0 & 0 \\
\hline \multicolumn{9}{|l|}{ Aracnida } \\
\hline Acarina & 2 & 1 & 0 & 1 & 0 & 1 & 0 & 1 \\
\hline \multicolumn{9}{|l|}{ Insecta } \\
\hline \multicolumn{9}{|l|}{ Coleoptera } \\
\hline Dytiscidae & 6 & 0 & 0 & 0 & 1 & 0 & 0 & 2 \\
\hline Elmidae & 51 & 35 & 18 & 21 & 11 & 12 & 37 & 34 \\
\hline Hydrophilidae & 1 & 0 & 0 & 0 & 0 & 0 & 1 & 0 \\
\hline Psephenidae & 0 & 8 & 1 & 0 & 0 & 3 & 5 & 0 \\
\hline Ptylodactilidae & 0 & 0 & 0 & 1 & 0 & 0 & 0 & 0 \\
\hline \multicolumn{9}{|l|}{ Diptera } \\
\hline Blephariceridae & 0 & 0 & 0 & 0 & 0 & 0 & 0 & 2 \\
\hline Ceratopogonidade & 1 & 2 & 0 & 5 & 1 & 1 & 0 & 0 \\
\hline Chironomidae & 56 & 135 & 270 & 214 & 92 & 42 & 54 & 38 \\
\hline Culicidae & 0 & 0 & 1 & 0 & 0 & 1 & 0 & 0 \\
\hline Simuliidae & 2 & 19 & 19 & 14 & 4 & 10 & 17 & 25 \\
\hline \multicolumn{9}{|l|}{ Ephemeroptera } \\
\hline Baetidae & 6 & 39 & 25 & 26 & 6 & 32 & 81 & 17 \\
\hline Caenidae & 0 & 13 & 5 & 14 & 0 & 16 & 15 & 1 \\
\hline Leptohyphidae & 0 & 65 & 39 & 32 & 15 & 30 & 32 & 8 \\
\hline Leptophlebiidae & 47 & 60 & 33 & 46 & 18 & 25 & 61 & 26 \\
\hline Oligoneuriidae & 0 & 1 & 0 & 0 & 1 & 0 & 0 & 0 \\
\hline \multicolumn{9}{|l|}{ Hemiptera } \\
\hline Gerridae & 0 & 0 & 1 & 0 & 0 & 0 & 0 & 0 \\
\hline Helotrephidae & 0 & 2 & 0 & 0 & 0 & 0 & 0 & 0 \\
\hline Naucoridae & 0 & 8 & 0 & 0 & 0 & 0 & 0 & 0 \\
\hline Veliidae & 0 & 0 & 0 & 0 & 1 & 0 & 0 & 0 \\
\hline \multicolumn{9}{|l|}{ Lepidoptera } \\
\hline Pyralidae & 0 & 1 & 0 & 0 & 0 & 0 & 0 & 0 \\
\hline \multicolumn{9}{|l|}{ Odonata } \\
\hline Aeshnidae & 0 & 1 & 0 & 2 & 1 & 0 & 0 & 0 \\
\hline Calopterygidae & 0 & 2 & 2 & 0 & 0 & 1 & 0 & 0 \\
\hline
\end{tabular}


Table 1. Continued...

\begin{tabular}{|c|c|c|c|c|c|c|c|c|}
\hline \multirow{2}{*}{ Taxa } & \multicolumn{4}{|c|}{ Leãozinho River } & \multicolumn{4}{|c|}{ Ligeirinho River } \\
\hline & ST1 & ST2 & ST3 & ST4 & ST1 & ST2 & ST3 & ST4 \\
\hline Gomphidae & 0 & 0 & 0 & 1 & 0 & 0 & 0 & 0 \\
\hline Libellulidae & 1 & 0 & 4 & 1 & 14 & 2 & 0 & 0 \\
\hline Megapodagrionidae & 4 & 6 & 4 & 9 & 0 & 0 & 2 & 1 \\
\hline \multicolumn{9}{|l|}{ Plecoptera } \\
\hline Gripopterygidae & 0 & 11 & 12 & 7 & 4 & 26 & 32 & 4 \\
\hline Perlidae & 0 & 0 & 2 & 0 & 0 & 2 & 1 & 0 \\
\hline \multicolumn{9}{|l|}{ Trichoptera } \\
\hline Anomalopsychidae & 3 & 1 & 0 & 0 & 0 & 1 & 0 & 0 \\
\hline Glossosomatidae & 0 & 0 & 0 & 0 & 0 & 0 & 0 & 22 \\
\hline Hydrobiosidae & 39 & 46 & 123 & 65 & 64 & 117 & 116 & 14 \\
\hline Hydroptilidae & 0 & 1 & 3 & 0 & 0 & 2 & 1 & 0 \\
\hline Hydropsychidae & 54 & 21 & 117 & 81 & 57 & 126 & 117 & 39 \\
\hline Leptoceridae & 7 & 0 & 8 & 21 & 35 & 0 & 1 & 1 \\
\hline Odontoceridae & 9 & 30 & 42 & 60 & 2 & 24 & 31 & 19 \\
\hline Philopotamidae & 0 & 0 & 15 & 3 & 0 & 0 & 0 & 0 \\
\hline Xyphocentronidae & 0 & 7 & 4 & 0 & 2 & 0 & 8 & 1 \\
\hline $\begin{array}{l}\text { Total abundance } \\
\text { Mean } \pm \text { sd } \\
\min -\max \end{array}$ & $\begin{array}{c}324 \\
81.6 \pm \\
130.8 \\
1-344\end{array}$ & $\begin{array}{c}541 \\
81 \pm \\
66.9 \\
13-177\end{array}$ & $\begin{array}{c}751 \\
103.3 \pm \\
59.6 \\
42-195\end{array}$ & $\begin{array}{c}628 \\
43 \pm \\
34.1 \\
13-88\end{array}$ & $\begin{array}{c}490 \\
54.2 \pm \\
28.15 \\
24-94\end{array}$ & $\begin{array}{c}486 \\
90.3 \pm \\
39.2 \\
43-157\end{array}$ & $\begin{array}{c}619 \\
120.3 \pm \\
70.7 \\
39-232\end{array}$ & $\begin{array}{c}257 \\
104.8 \pm \\
44.3 \\
48-156\end{array}$ \\
\hline $\begin{array}{l}\text { Total richness } \\
\text { Mean } \pm \text { sd } \\
\text { min - max }\end{array}$ & $\begin{array}{c}19 \\
6.6 \pm 5.6 \\
1-17\end{array}$ & $\begin{array}{c}28 \\
10 \pm 4.3 \\
3-16\end{array}$ & $\begin{array}{c}23 \\
12.6 \pm 2.4 \\
10-16\end{array}$ & $\begin{array}{c}21 \\
8.5 \pm 0.8 \\
7-9\end{array}$ & $\begin{array}{c}21 \\
9.6 \pm 3.3 \\
7-16\end{array}$ & $\begin{array}{c}23 \\
15 \pm 2.2 \\
12-18\end{array}$ & $\begin{array}{c}20 \\
11.8 \pm 2.5 \\
8-14\end{array}$ & $\begin{array}{c}19 \\
11.5 \pm 1.4 \\
10-13\end{array}$ \\
\hline
\end{tabular}

The most abundant families were Chironomidae (21\%) of the order Diptera and Hydropsychidae (15\%) of the order Trichoptera.

A total of 1,243 specimens from the orders Ephemeroptera, Plecoptera and Trichoptera (EPT) were collected in Leãozinho River and 1,253 in Ligeirinho River, corresponding respectively to $55 \%$ and $67 \%$ of the total number of individuals. The order Trichoptera was the most abundant, both in total number of individuals (Leãozinho River: 760, Ligeirinho River: 800) and in total number of taxa (Leãozinho River: 8; Ligeirinho River: 8). There was no significant difference in EPT/EPT\%/EPT values (Table 2) between rivers $\left(F_{1,22}=0.004, \mathrm{p}=0.94\right)$ and among sites $\left(F_{7,16}=0.22, \mathrm{p}=0.97\right)$.

According to the BMWP' index, the waters of the Leãozinho River were classified as doubtful in site 1 (BMWP' index of 95 points, Table 2) and as good in sites 2, 3 and 4 (BMWP' index of 135,143 and 133 points). Ligeirinho River presented an acceptable rating in sites 1 and 4 (BMWP' index of 118 points) and was classified as good in sites 2 and 3 (BMWP' index of 123 and 122 points). The BMWP' index showed significant correlation with the abundance of organisms $(r=0.78, \mathrm{p}=0.02)$, richness of EPT $(r=0.85, \mathrm{p}=0.007)$ and BOD $(r=0.72, \mathrm{p}=0.04)$.

Among the physical, chemical and microbiological parameters evaluated (Table 3), those that varied significantly among the collection sites were turbidity $\left(F_{7,40}=8.98 ; \mathrm{p}<0.01\right.$, significant in ST2 - Ligeirinho River, $\mathrm{p}<0.05$, Tukey test), conductivity $\left(F_{7,40}=2.53 ; \mathrm{p}=0.03\right.$, significant in ST2 - Ligeirinho River, $\mathrm{p}<0.05$, Tukey test), $\mathrm{pH}\left(F_{7,40}=47.56, \mathrm{p}<0.01\right.$, significant in ST1 Ligeirinho River, $\mathrm{p}<0.05$, Tukey test), total coliforms $\left(F_{7,40}=3.44 ; \mathrm{p}<0.01\right.$, significant in ST3, Leãozinho River, $\mathrm{p}<0.05$, Tukey test $)$ and nitrate $\left(F_{7,40}=276.45\right.$, $\mathrm{p}<0.01$, significant for all ST, $\mathrm{p}<0.05$, Tukey test). The source of the Ligeirinho River (ST1) was the one with lower levels of temperature, $\mathrm{pH}$, dissolved oxygen, turbidity, BOD and total/fecal coliforms (Table 3).

Sites 3 and 4 of Leãozinho River showed total and fecal coliform values above the values established for Class 1 (Table 3). In the Leãozinho River, ST3 and ST4, and Ligeirinho River, ST2 had an elevated number of total coliforms. For other environmental parameters measured in the Leãozinho and Ligeirinho Rivers, the means were considered acceptable for Class 1 by Resolution No. 357/05 of CONAMA (Brasil, 2005). 
Table 2. Benthic macroinvertebrate (total indices) in the Leãozinho and Ligeirinho Rivers (Erechim, Rio Grande do Sul), by site (ST1-4), from November 2014 to April 2015.

\begin{tabular}{|c|c|c|c|c|c|c|c|c|}
\hline & \multicolumn{4}{|c|}{ Leãozinho River } & \multicolumn{4}{|c|}{ Ligeirinho River } \\
\hline & ST1 & ST2 & ST3 & ST4 & ST1 & ST2 & ST3 & ST4 \\
\hline Shannon index & 1.009 & 1.113 & 0.917 & 0.967 & 0.904 & 0.986 & 1.025 & 1.055 \\
\hline EPT & 165 & 295 & 428 & 355 & 204 & 401 & 496 & 152 \\
\hline EPT (\%) & $50 \%$ & $54 \%$ & $56 \%$ & $56 \%$ & $32 \%$ & $82 \%$ & $80 \%$ & $59 \%$ \\
\hline EPT richness & 7 & 12 & 13 & 10 & 10 & 11 & 12 & 11 \\
\hline BMWP' & 95 & 135 & 143 & 133 & 118 & 123 & 122 & 118 \\
\hline
\end{tabular}

Table 3. Values of physicochemical and microbiological parameters measured at sites along the Leãozinho and Ligeirinho Rivers (Erechim, Rio Grande do Sul), by site (ST1-4), from November 2014 to April 2015. (means \pm sd, min - max).

\begin{tabular}{|c|c|c|c|c|c|c|c|c|}
\hline \multirow{2}{*}{ Parameters } & \multicolumn{4}{|c|}{ Leãozinho River } & \multicolumn{4}{|c|}{ Ligeirinho River } \\
\hline & ST1 & ST2 & ST3 & ST4 & ST1 & ST2 & ST3 & ST4 \\
\hline Water temperature $\left({ }^{\circ} \mathrm{C}\right)$ & $\begin{array}{l}22.8 \pm 1.6 \\
21.6-25.6\end{array}$ & $\begin{array}{c}21.8 \pm 1.6 \\
20-23.9\end{array}$ & $\begin{array}{l}22.8 \pm 1.6 \\
21.6-25.6\end{array}$ & $\begin{array}{l}22.4 \pm 1.7 \\
20.7-25.4\end{array}$ & $\begin{array}{c}20.5 \pm 1.3 \\
19.3-23\end{array}$ & $\begin{array}{l}23.4 \pm 1.1 \\
21.9-24.8\end{array}$ & $\begin{array}{c}22.6 \pm 1.6 \\
20-24.5\end{array}$ & $\begin{array}{c}22.9 \pm 2 \\
20.5-25.5\end{array}$ \\
\hline $\mathrm{pH}$ & $\begin{array}{c}7.2 \pm 0.1 \\
7-7.3\end{array}$ & $\begin{array}{c}7.2 \pm 0.1 \\
7-7.4\end{array}$ & $\begin{array}{c}7.2 \pm 0.1 \\
7-7.3\end{array}$ & $\begin{array}{c}7.2 \pm 0.2 \\
7-7.5\end{array}$ & $\begin{array}{c}5.8 \pm 0.2 \\
5.6-6\end{array}$ & $\begin{array}{l}7.2 \pm 0.1 \\
6.9-7.3\end{array}$ & $\begin{array}{l}7.1 \pm 0.2 \\
6.7-7.3\end{array}$ & $\begin{array}{l}7.1 \pm 0.1 \\
6.9-7.4\end{array}$ \\
\hline Dissolved oxygen (mg/L) & $\begin{array}{l}6.1 \pm 0.7 \\
4.8-6.9 \\
\end{array}$ & $\begin{array}{l}6.2 \pm 1.1 \\
4.3-7.6 \\
\end{array}$ & $\begin{array}{l}6.1 \pm 0.7 \\
4.8-6.9 \\
\end{array}$ & $\begin{array}{l}6.2 \pm 1.2 \\
4.5-7.4 \\
\end{array}$ & $\begin{array}{c}4.8 \pm 0.6 \\
4-5.33\end{array}$ & $\begin{array}{l}6.4 \pm 0.6 \\
5.2-6.9\end{array}$ & $\begin{array}{l}6.1 \pm 0.9 \\
4.9-7.3 \\
\end{array}$ & $\begin{array}{c}5.8 \pm 0.4 \\
5-6.3\end{array}$ \\
\hline Turbidity (NTU) & $\begin{array}{c}17.9 \pm 4.3 \\
13.3-24.3\end{array}$ & $\begin{array}{c}7.9 \pm 2 \\
5.2-10.9\end{array}$ & $\begin{array}{r}17.4 \pm 8.8 \\
10.4-29.5\end{array}$ & $\begin{array}{c}19.1 \pm 6.4 \\
10.2-29.8\end{array}$ & $\begin{array}{c}2.1 \pm 3 \\
0.3-8.2\end{array}$ & $\begin{array}{c}39.6 \pm 19.3 \\
9.4-63.4\end{array}$ & $\begin{array}{l}13.2 \pm 5.6 \\
6.6-21.5\end{array}$ & $\begin{array}{c}17.9 \pm 4.3 \\
13.3-24.3\end{array}$ \\
\hline $\mathrm{BOD}_{5}(\mathrm{mg} / \mathrm{L})$ & $\begin{array}{l}1.6 \pm 0.9 \\
0.8-3.5\end{array}$ & $\begin{array}{l}1.9 \pm 1.3 \\
0.7-3.9\end{array}$ & $\begin{array}{c}1.6 \pm 0.9 \\
1-3.3\end{array}$ & $\begin{array}{c}1.6 \pm 0.9 \\
0.5-3\end{array}$ & $\begin{array}{c}1.3 \pm 0.8 \\
0.8-3\end{array}$ & $\begin{array}{c}1.5 \pm 0.8 \\
0.7-3\end{array}$ & $\begin{array}{c}3 \pm 0.8 \\
1-3\end{array}$ & $\begin{array}{c}2.1 \pm 1.1 \\
0.5-3\end{array}$ \\
\hline Conductivity $(\mu \mathrm{S} / \mathrm{cm})$ & $\begin{array}{c}54.8 \pm 5.9 \\
44-60.3\end{array}$ & $\begin{array}{c}55.8 \pm 9.1 \\
42-68.6\end{array}$ & $\begin{array}{c}54.8 \pm 5.9 \\
44-60.3\end{array}$ & $\begin{array}{c}51.2 \pm 11.3 \\
32-62.4\end{array}$ & $\begin{array}{c}59.4 \pm 10.5 \\
51-77.9\end{array}$ & $\begin{array}{l}70.9 \pm 8.1 \\
61.1-78.1\end{array}$ & $\begin{array}{c}62 \pm 4.3 \\
35.1-78.1\end{array}$ & $\begin{array}{c}58.6 \pm 5.2 \\
52.6-68.1\end{array}$ \\
\hline Nitrate $(\mathrm{mg} / \mathrm{L})$ & $\begin{array}{c}1 \pm 0.01 \\
1-1.01\end{array}$ & $\begin{array}{c}0.3 \pm 0.02 \\
0.3-0.4\end{array}$ & $\begin{array}{c}0.5 \pm 0.02 \\
0.52-0.57\end{array}$ & $\begin{array}{l}0.5 \pm 0.02 \\
0.5-0.54\end{array}$ & $\begin{array}{c}1.1 \pm 0.1 \\
1-1.3\end{array}$ & $\begin{array}{l}0.3 \pm 0.01 \\
0.3-0.33\end{array}$ & $\begin{array}{c}0.4 \pm 0.02 \\
0.4-0.45\end{array}$ & $\begin{array}{l}0.2 \pm 0.02 \\
0.2-0.26\end{array}$ \\
\hline Total coliforms $/ \mathrm{mL}$ & $\begin{array}{c}174 \pm \\
89.3 \\
28-240\end{array}$ & $\begin{array}{c}50.16 \pm \\
54 . \\
37-120\end{array}$ & $\begin{array}{c}1197.66 \pm \\
1034.4 \\
93-2400\end{array}$ & $\begin{array}{c}980.16 \pm \\
1113.6 \\
11-2400\end{array}$ & $\begin{array}{c}7.5 \pm \\
7.9 \\
3-23\end{array}$ & $\begin{array}{c}540 \pm \\
912.5 \\
120-2400\end{array}$ & $\begin{array}{c}58.8 \pm \\
39.5 \\
3-93\end{array}$ & $\begin{array}{c}32 \pm \\
23.3 \\
14-75\end{array}$ \\
\hline Fecal coliforms $/ \mathrm{mL}$ & $\begin{array}{l}125 \pm \\
189.9 \\
9-460\end{array}$ & $\begin{array}{c}9.83 \pm \\
5.5 \\
3-20\end{array}$ & $\begin{array}{c}521 \pm \\
922.1 \\
93-2400\end{array}$ & $\begin{array}{c}854.8 \pm \\
1197.7 \\
11-2400\end{array}$ & $\begin{array}{c}3 \pm \\
0 \\
3-3\end{array}$ & $\begin{array}{c}36.3 \pm \\
29.3 \\
15-93\end{array}$ & $\begin{array}{c}5 \pm \\
4.9 \\
3-15\end{array}$ & $\begin{array}{c}8.6 \pm \\
5.4 \\
3-15\end{array}$ \\
\hline
\end{tabular}

\section{Discussion}

The analysis of river water quality carried out through biomonitoring with benthic macroinvertebrates, as well as through physicochemical and microbiological parameters, was shown to be good, as classified in Classes 1 and 2 of Resolution No. 357/05 of CONAMA (Brasil, 2005). However, the integrated analysis of various parameters along the river showed degradation of water quality in places. It was expected that the sources of the rivers would present better water quality, but the source of the Leãozinho River was classified as doubtful by the BMWP' index, with a decrease in richness and abundance of EPT and pollution by the Shannon index. This spring is located next to residential and recreational areas which may be contributing to the reduction of water quality.

The source of the Ligeirinho River was classified by BMWP' as acceptable, lower than the classification at the two following sites in the same river. The spring is located in an area of agricultural cultivation and its surroundings have riparian vegetation fragments (Erechim, 2011). This site distinguished itself by presenting lower temperature, $\mathrm{pH}$, dissolved oxygen, turbidity, BOD, and lower Shannon diversity. The decrease in the amount of dissolved oxygen was related to the reduced speed of the water and lower turbulence, which probably resulted in reduced oxygen transfer from the air to the water (Von Sperling, 2005). The substrate of this spring was composed predominantly of sediment, with few places for organisms to settle (pers. obs.) and with less oxygen. This site appears to be less suitable for organisms that are indicators of good water quality, resulting in a BMWP' classification of acceptable.

The BMWP' index uses the sensitivity of organisms associated with water quality, and the highest values of the index are attributed to the richness of families sensitive to pollution and that, therefore, belong to the orders Ephemeroptera, Plecoptera and Trichoptera (Monteiro et al., 2008; 
Loyola, 2000; Reice \& Wohlenberg, 1993). Thus, the results of BMWP' can be explained by its correlation with EPT richness (Dang et al., 2009). The abundance of macroinvertebrates is not used for calculating the BMWP', however, it was also associated with the results of the index, given the diversity of families. The best water quality was found in the intermediate sites of the Leãozinho and Ligeirinho Rivers (ST2 and ST3). The highest values in terms of abundance of macroinvertebrates were also obtained in this section. Therefore, the sites with lowest abundances of macroinvertebrates had lower values of BMWP'.

If the results of the EPT index are analyzed independently, the analysis indicates good water quality along both rivers. Using this index, water quality is considered poor when the percentage of EPT is less than 24\% (Carrera \& Fierro, 2001). Considering this, the results indicate that only the source of the Ligeirinho River has a lower water quality (32\% EPT). The Leãozinho and Ligeirinho Rivers have constant water oxygenation that aids in their self-purification process, favoring the presence of EPT groups (Hepp \& Restello, 2010). High abundance of Ephemeroptera, Plecoptera and Trichoptera (EPT), seems to indicate environments that are still relatively conserved (Galdean et al., 2000).

The EPT make up a rich set of taxa that occur in low- and middle-order streams. The genera of these organisms are more sensitive to environmental disturbances, and occur mainly in clean and well oxygenated waters (Pitágoras \& Oliveira, 2007), being associated with less degraded environments (Bispo et al., 2001). Several factors can influence the distribution of EPT, including the types of substrates (Silveira et al., 2006), the diversity of habitats, the speed of the current and the availability of trophic resources (Crisci-Bispo et al., 2007).

When analyzing the Shannon index, the results indicate decreased water quality, despite the results of the EPT (good water quality) and BMWP' (water classified as doubtful, good and acceptable) indices being favorable for water quality. The diversity values showed water pollution at a moderate level. The Leãozinho and Ligeirinho Rivers $\left(\mathrm{H}^{\prime}=0.9045\right.$ to 1.113$)$ were classified as having water pollution (Barbosa et al., 2001) with levels of strong and moderate pollution (Wilhm \& Dorris, 1968). The Shannon diversity index may decrease in response to impact on the environment (Silveira, 2004; Teles et al., 1996). Perhaps this diversity was influenced by the dominance of a few families, as in the case of Chironomidae.

The family Chironomidae was most abundant in both the Leãozinho and Ligeirinho Rivers, being among the most densely populated groups of macroinvertebrates and generally appearing as dominant in both lentic and lotic environments, a fact that is due to the tolerance of certain species to extreme situations such as hypoxia (Di Giovanni et al., 1996; Pamplin \& Rocha, 2007). Thus, high densities of representatives of this family may indicate high levels of organic matter in the environment, which make them effective indicators of environmental degradation (Barbola et al., 2011; Oliveira et al., 2010).

Regarding physical and chemical parameters, fluctuations in the results of the significant variables $(\mathrm{pH}$, turbidity, conductivity, nitrate and total coliforms) occurred mainly in the months of December, January and April, including periods with temperatures between $11^{\circ} \mathrm{C}$ and $33^{\circ} \mathrm{C}$, with rainfall between $1 \mathrm{~mm}$ and $65 \mathrm{~mm}$ (INMET, 2015). The $\mathrm{pH}$ of most samples was around neutral, that is, between 6.5 and 7.5, results that favor most microorganisms (Ribeiro et al., 2005).

Turbidity values are associated with the supply of allochthonous material and also with sediment disturbance which generates a decrease in water clarity. The increase in turbidity is directly related to the increase in the concentration of suspended solids (Ribeiro et al., 2005). Turbidity in the water is caused by the presence of organic and inorganic matter in suspension (Esteves, 1998; Gonçalves et al., 2012). An increase in turbidity is also common in rainy periods and can be related to the amount of organic matter available. Average turbidity ranged from 2.1 to 45.64 NTU, results that meet the legislation levels (Brasil, 2005).

In the study by Trevisan et al. (2009), in the basin of Jacutinga River (Rio Grande do Sul), near the study area, the water had a low concentration of dissolved ions and values greater than $90 \mu \mathrm{s} / \mathrm{cm}$ of electrical conductivity were not observed, characterizing the water as natural due to the low conductivity values (Brigante et al., 2003). Thus, regarding conductivity, that ranged from 51.2 to $70.9 \mu \mathrm{s} / \mathrm{cm}$, the Leãozinho and Ligeirinho rivers could be classified as natural.

Although the nitrate values meet legislation levels (up to $10 \mathrm{mg} / \mathrm{L}$ ) it is noted that the source (ST1) in both streams is located near a plantation, which could be a possible explanation for the variation found. The presence of nitrogen in the form of nitrate 
is associated with anthropogenic contamination due to domestic and industrial sewage, animal excrement and fertilizers (Von Sperling, 2005). The study area is basically composed of a rural area with agricultural predominance thus the possibility of contamination of industrial origin can be discarded. The nitrate concentrations found in all samples were below the required standards for Classes 1 and 2 (Brasil, 2005).

Some samples were found unfit for human consumption during the sampling period, according to Resolution No. 274/00 of CONAMA (Brasil, 2001). These data may be related to the release of sewage or animal waste into the river, since the presence of these bacteria and the increase in BOD characterize this type of contamination. It is important to report that the rural population of Erechim city uses the water sources as a direct source for drinking, and this was detected at some sites of the analyzed rivers. For this use, Resolution No. 274/00 of CONAMA determines the absence of coliforms in any situation, including wells, mines, springs, and lakes, among others (Brasil, 2001).

The contamination found indicates the presence of fecal material. These results may reveal that the daily deposition of animal organic waste in the soil (a very widespread practice in rural areas), increases the risk of contamination of water and that the runoff during the rainy period is the factor that contributes most to changes in microbiological quality (Amaral et al., 2003; Sterz et al., 2011). The municipality of Erechim does not have a sewage collection and treatment system, as the sewage is directed into septic tanks and sinks (IBGE, 2014). Thus, the urban watercourses and springs are subjected to a high load of organic and inorganic pollutants.

In this study, the integrated analysis of water quality showed that the river basins of the Leãozinho and Ligeirinho Rivers presented sites with water quality degradation. This indication is evidenced in stretches characterized by doubtful BMWP' water quality, and water pollution by the Shannon Wiener diversity index, as well as contamination by total and fecal coliforms. The most relevant information is the fact that the sources of the rivers studied present water classification as doubtful and acceptable (BMWP') and water pollution (Shannon). Other studies indicate sources of rivers with results showing evidence of pollution (Buss et al., 2003; Callisto \& Moreno, 2004; Hepp \& Restello, 2007) but when dealing with the public supply rivers, this is a warning that should be taken into account by management systems. One of the main problems is the fact that the riparian vegetation in the study area is scarce or absent (Erechim, 2011). The presence of riparian forest is linked to water supply volume and quality (Ribeiro et al., 2014), and lack of vegetation could promote pollution.

According to the fluvial hierarchy of Strahler (1952), the basin of the Leãozinho River was defined as fourth order, and that of the Ligeirinho River as third order, both considered rivers with insufficient or deficient flow in time of drought or even of low seasonal precipitation. The municipality has experienced periods of drought (2005, 2009, 2011 and 2012) which seem to be cyclical. This requires effective public planning and management actions for the water resources in order to ensure the provision of water in terms of quality and quantity needed to supply the municipality (Bernardi, 2014).

The rivers of this study supply about 100 thousand inhabitants, showing the importance of studies in similar sized river basins, due to the high water consumption, increasing urban population and practice of agriculture on the riverbanks. Biomonitoring constitutes an effective tool for assessing the water quality, in order to guarantee the quality and availability of water. Thus, this study reinforces the importance of integrated studies that enable assessments for maintaining and restoring the integrity of these ecosystems (Barbola et al., 2011; Giuliatti \& Carvalho, 2009).

In order for these sources to be used for public supply, the importance of continuous environmental monitoring over the entire length of the river basin through physical, chemical and biological measures, is highlighted. Studies on geological and climatic characteristics are also suggested for the construction of regional assessment parameters. Such actions are necessary in order to guarantee environmental quality and water quality of these river basins, preventing public health problems for the population and enabling the maintenance of a diverse aquatic biota.

\section{References}

ALBA-TERCEDOR, J. Macroinvertebrados acuáticos y calidad de las aguas de los ríos. In: Anales del IV Simposio del água em Andalucía (SIAGA). Almería, 1996, pp. 203-213.

AMARAL, L.A., NADER FILHO, A., ROSSI JUNIOR, O.D., FERREIRA, F.L.A. and BARROS, L.S.S. Água de consumo humano como fator de risco à saúde em propriedades rurais. Revista de Saude Publica, 2003, 
37(4), 510-514. PMid:12937713. http://dx.doi. org/10.1590/S0034-89102003000400017.

AMERICAN PUBLIC HEALTH ASSOCIATION APHA. Standard methods for examination of water and wastewater. 19. ed. Washington: EPS Group, 1999. $1268 \mathrm{p}$.

ANDREWS, W.H., POELMA, P.L. and WILSON, C.R. Isolation and identification of Salmonella species. In: FOOD AND DRUG ADMINISTRATION. Bacteriological analytical manual. 6. ed. Arlington: AOAC, 1984, pp. 701-717.

BARBOLA, I.F., MORAES, M.F.P.G., ANAZAWA, T.M., NASCIMENTO, E.A., SEPKA, E.R., POLEGATTO, C.M., MILLÉO, J. and SCHÜHLI, G.S. Avaliação da comunidade de macroinvertebrados aquáticos como ferramenta para o monitoramento de um reservatório na bacia do rio Pitangui, Paraná, Brasil. Iheringia: Série Zoologia, 2011, 101(2), 15-23. http://dx.doi.org/10.1590/S007347212011000100002 .

BARBOSA, F.A.R., CALLISTO, M. and GALDEAN, $\mathrm{N}$. The diversity of benthic macroinvertebrates as an indicator of water quality and ecosystem health: a case study for Brazil. Aquatic Ecosystem Health and Management Society, 2001, 4(1), 51-59. http:// dx.doi.org/10.1080/146349801753569270.

BAS, D. and BOYACI, I. Modeling and optimization I: usability of response surface methodology. Journal of Food Engineering, 2007, 78(3), 836-845. http:// dx.doi.org/10.1016/j.jfoodeng.2005.11.024.

BERNARDI, L. Análise da gestão dos recursos hídricos no município de Erechim. Revista Monografias Ambientais, 2014, 14(2), 3026-3039.

BISPO, P.C., OLIVEIRA, L.G., CRISCI, V.L. and SILVA, M.M. A pluviosidade como fator de alteração da entomofauna bentônica (Ephemeroptera, Plecoptera e Trichoptera) em córregos do Planalto Central do Brasil. Acta Limnologica Brasiliensia, 2001, 13(2), 1-9.

BRASIL Ministério do Meio Ambiente - MMA. Conselho Nacional de Meio Ambiente - CONAMA. Resolução no 274, de 29 de novembro de 2000. Recomenda a adoção de sistemáticas de avaliação de qualidade das águas. Diário Oficial da União [online], Poder Executivo, Brasília, DF, 25 jan. 2001 [viewed 16 July 2015]. Available from: http://www.cetesb. sp.gov.br/Agua/praias/res_conama_274_00.pdf

BRASIL. Resoluçáo CONAMA nº 357, de 17 de março de 2005. Classificação das águas doces, salobras e salinas do território nacional. Diário Oficial da Uniāo, Poder Executivo, Brasília, DF, 18 mar. 2005, pp. 58-63.

BRIGANTE, J., DORNFELD, C.B., NOVELLI, A. and MORRAYE, M.A. Comunidade de macroinvertebrados bentônicos no rio Mogi-Guaçu. In: J. BRIGANTE and E.L.G. ESPÍNDOLA.
Limnologia fluvial: um estudo no rio Mogi-Guaçu. São Carlos: Rima, 2003, pp. 181-187.

BUSS, D.F., BAPTISTA, D.F. and NESSIMIAN, J.L. Bases conceituais para a aplicação de biomonitoramento em programas de avaliação da qualidade da água de rios. Cadernos de Saúde Pública, 2003, 19(2), 465-473. http://dx.doi.org/10.1590/ S0102-311X2003000200013.

CALLISTO, M. and MORENO, P. Bioindicadores de qualidade de água ao longo da bacia do Rio das Velhas. In: V.L. FERRACINI, S.C.N. QUEIROZ and M.P. SILVEIRA. Bioindicadores de qualidade da água. 1. ed. Jaguariuna: EMBRAPA, 2004. vol. 1, cap. 5.

CARRERA, C. and FIERRO, K. Manual de monitoreo: los macroinvertebrados acuáticos como indicadores de la calidad del água. Quito: EcoCiência, 2001.

CORGOSINHO, P.H.C., CALIXTO, L.S.F., FERNANDES, P.L., GAGLIARDI, L.M. and BALSAMÃO, V.L.P. Diversidade de habitats e padróes de diversidade e abundância dos bentos ao longo de um afluente do reservatório de Três Marias, MG. Arquivos do Instituto Biologico, 2004, 71(2), 227-232.

COSTA, F.L.M., OLIVEIRA, A. and CALLISTO, M. Inventário da diversidade de macroinvertebrados bentônicos no reservatório da estação ambiental de Peti, MG, Brasil. Neotropical Biology and Conservation, 2006, 1(1), 17-23.

CRISCI-BISPO, V.L., BISPO, P.C. and FROEHLICH, C.G. Ephemeroptera, Plecoptera and Trichoptera assemblages in two Atlantic Rainforest streams, Southeastern Brazil. Revista Brasileira de Zoologia, 2007, 24(2), 312-318. http://dx.doi.org/10.1590/ S0101-81752007000200007.

DANG, C.K., HARRISON, S., STURT, M.M., GILLER, P.S. and JANSEN, M.A.K. Is the elemental composition of stream invertebrates a determinant of tolerance to organic pollution? Journal of the North American Benthological Society, 2009, 28(4), 778-784. http://dx.doi.org/10.1899/08-163.1.

DI GIOVANNI, M.V., GORETTI, E. and TAMANTI, V. Macrobenthos in Montedoglio Reservoir, central Italy. Hydrobiologia, 1996, 321(1), 17-28. http:// dx.doi.org/10.1007/BF00018673.

ERECHIM. Plano de manejo da Área de Proteção Ambiental dos rios Ligeirinho e Leãozinho. Erechim, 2011 [viewed 26 June 2014]. Available from: http://www.pmerechim.rs.gov.br/uploads/files/ Plano_Manejo_APA_Rios_Ligeirinho_Leaozinho_ Dez_2011.pdf

ESTEVES, F.A. Fundamentos de limnologia. 2. ed. Rio de Janeiro: Interbio, 1998.

GALDEAN, N., CALLISTO, M., BARBOSA, F.A.R. and ROCHA, L.A. Lotic ecosystems of Serra do Cipó, Southeast Brazil: water quality and a tentative 
classification based on the benthic macroinvertebrate community. Journal of Aquatic Ecosystem Health \& Restoration, 2000, 3, 545-552.

GIULIATTI, T.L. and CARVALHO, E.M. Distribuição das assembleias de macroinvertebrados bentônicos em dois trechos do córrego Laranja Doce, Dourados/MS. Interbio, 2009, 3(1), 4-14.

GONÇALVES, J.C.S.I., SARDINHA, D.S., SOUZA, A.D.G., DIBIAZI, A.L.B., GODOY, L.H. and CONCEIÇÃO, F.T. Avaliação espaço temporal da qualidade da água e simulação de autodepuração na bacia hidrográfica do córrego São Simão, SP. Environ and Water, 2012, 7(3), 141-154.

GOONETILEKE, A., YGITCANLAR, T., AYOKO, G.A. and EGODAWATTA, P. Sustentainable urban water environment: climate, pollution, adaptation. Edward Elgar Publishing, 2014.

GORSKI, M.C.B. Rios e cidades: ruptura e reconciliação. São Paulo: Senac, 2010.

GOULART, M.D.C. and CALLISTO, M. Bioindicadores de qualidade de água como ferramenta em estudos de impacto ambiental. Revista da Faculdade de Pará de Minas, 2003, 2(1), 153-164.

HEPP, L.U. and RESTELLO, R.M. Macroinvertebrados bentônicos como bioindicadores da qualidade das águas do Alto Uruguai Gaúcho. In: S.B. ZAKRZEVISKI. Conservação e uso sustentável da água: múltiplos olhares. Erechim: Edifapes, 2007.

HEPP, L.U. and RESTELLO, R.M. Macroinvertebrados bentônicos como ferramenta para avaliação de impactos resultantes dos usos da terra. In: J.E. SANTOS, E.M. ZANIN and L.E. MOSCHINI, eds. Faces da polissemia da paisagem: ecologia, planejamento e percepção. São Carlos: Rima, 2010, pp. 264-277.

HEPP, L.U., MILESI, S.V., BIASI, C. and RESTELLO, R.M. Macroinvertebrados Bentônicos como bioindicadores da qualidade das águas. In: Anais do $17^{\circ}$ Simpósio Brasileiro de Recursos Hidricos; $8^{\circ}$ Simpósio de Hidráulica e Recursos Hidricos dos países de Lingua Oficial Portuguesa. São Paulo: ABRH, 2007.

HEPP, L.U., MILESI, S.V., BIASI, C. and RESTELLO, R.M. Effects ofagricultural and urban impacts on macroinvertebrates assemblages in streams (Rio Grande do Sul, Brazil). Revista Brasileira de Zoologia, 2010, 27(1), 106-113.

INSTITUTO BRASILEIRO DE GEOGRAFIA E ESTATÍSTICA - IBGE [online]. Rio de Janeiro: IBGE, 2014 [viewed 26 Apr. 2014]. Available from: http://www.cidades.ibge.gov.br/xtras/perfil. php ?lang=\&codmun $=430700 \&$ search $=$ rio-grand e-do-sul|erechim

INSTITUTO NACIONAL DE METEREOLOGIA INMET [online]. Brasília: INMET, 2015 [viewed 26 June 2015]. Available from: http://www.inmet. gov.br/portal/index.php? $\mathrm{r}=$ home/ page\&page=rede_ estacoes_auto_graf
KÖNIG, R., SUZIN, C.R.H., RESTELLO, R.M. and HEPP, L.U. Qualidade das águas de rios da regiáo norte do Rio Grande do Sul (Brasil) através de variáveis físicas, químicas e biológicas. Pan-American Journal of Aquatic Sciences, 2008, 3(1), 84-93.

LIMA, J.S. Bioindicação, biomonitoramento: aspectos bioquímicos e morfológicos. Belo Horizonte: Techoje, Instituto de Educação Tecnológica, 2000.

LOYOLA, R.G.N. Atual estágio do IAP de índices biológicos de qualidade. In: Anais do V Simpósio de Ecossistemas Brasileiros: Conservação. Vitória: ACIESP, 2000.

MAGURRAN, A.E. Measuring biological diversity. Malden: Blackwell Publishing, 2004.

METCALFE, J.L. Biological water quality assessment of running waters based on macroinvertebrate communities: history and present status in Europe. Environmental Pollution, 1989, 60(1-2), 101-139. PMid:15092393. http://dx.doi.org/10.1016/02697491(89)90223-6.

MONTEIRO, T.R., OLIVEIRA, L.G. and GODOY, B.S. Biomonitoramento da qualidade de água utilizando macroinvertebrados bentônicos: adaptação do índice biótico BMWP' à bacia do Rio Meia PonteGO. Oecologia Brasiliensis, 2008, 12(3), 553-563.

MUGNAI, R., NESSIMIAN, J.L. and BAPTISTA, D.F. Manual de Identificação de Macroinvertebrados Aquáticos do Estado do Rio de Janeiro. Rio de Janeiro: Tecnical Books, 2010.

OLIVEIRA, V., MARTINS, R. and ALVES, R. Evaluation of water quality of an urban stream in southeastern Brazil using Chironomidae larvae (Insecta: Diptera). Neotropical Entomology, 2010, 39(6), 873-878. PMid:21271051. http://dx.doi. org/10.1590/S1519-566X2010000600004.

PAMPLIN, P.A.Z. and ROCHA, O. Temporal and bathymetric distribution of benthic macroinvertebrates in the Ponte Nova Reservoir, Tietê river (São Paulo, Brazil). Acta Limnologica Brasiliensia, 2007, 19, 439-452.

PARANÁ. Secretaria do Meio Ambiente e Recursos Hídricos. Avaliação da qualidade da água através dos macroinvertebrados bentônicos: indice BMWP [online]. Curitiba, 2014 [viewed 10 Apr. 2014]. Available from: http://www.meioambiente.pr.gov.br/modules/ conteudo/conteudo.php? conteudo $=91$

PITÁGORAS, C.B. and OLIVEIRA, L.G. Diversity and structure of Ephemeroptera, Plecoptera and Trichoptera (Insecta) assemblages from riffles in mountain streams of Central Brazil. Revista Brasileira de Zoologia, 2007, 24(2), 283-293. http://dx.doi. org/10.1590/S0101-81752007000200004.

REICE, S.R. and WOHLENBERG, M. Monitoring freshwater benthic macroinvertebrates and benthic processes: Measures for assessment of ecosystem health. In: V.H. RESH and D.M. ROSENBERG. Freshwater 
biomonitoring and benthic macroinvertebrates. 1. ed. Chapman \& Hall, 1993, pp. 287-305.

RIBEIRO, K.H., FAVARETTO, N., DIECKOW, J., SOUZA, L.C.P., MINELLA, J.P.G., ALMEIDA, L. and RAMOS, M.R. Quality of surface water related to land use: a case study in a catchment with small farms and intensive vegetable crop production in southern Brazil. Revista Brasileira de Ciência do Solo, 2014, 38(2), 656-668. http://dx.doi.org/10.1590/ S0100-06832014000200030.

RIBEIRO, T.A.P., AIROLDI, R.P.S., PATERNIANI, J.E.S. and SILVA, M.J.M. Variação dos parâmetros físicos, químicos e biológicos da água em um sistema de irrigação localizada. Revista Brasileira de Engenharia Agricola e Ambiental, 2005, 9(3), 295-301. http:// dx.doi.org/10.1590/S1415-43662005000300001.

RODRIGUES, W.C. DivEs: diversidade de espécies. Versão 3.0. Software e guia do usuário [software]. 2015 [viewed 26 June 2015]. Available from: http://dives. ebras.bio.br/downloads.aspx

SILVEIRA, M.P. Aplicação do biomonitoramento para avaliação da qualidade da água em rios. São Paulo: EMBRAPA, 2004. Documentos, no. 36.

SILVEIRA, M.P., BUSS, D.F., NESSIMIAN, J.L. and BAPTISTA, D.F. Spatial and temporal distribution of benthic macroinvertebrates in a Southeastern Brazilian river. Brazilian Journal of Biology $=$ Revista Brasileira de Biologia, 2006, 66(2B), 623-632. PMid:16906294. http://dx.doi.org/10.1590/S151969842006000400006.

STERZ, C., ROZA-GOMES, M. and ROSSI, E.M. Análise microbiológica e avaliação de macroinvertebrados bentônicos como bioindicadores da qualidade da água do Riacho Capivara, município de Mondaí, SC. Unoesc \& Ciência, 2011, 2(1), 7-16.

STRAHLER, A.N. Hypsometric (area-altitude): analysis of erosional topography. Geological Society of America Bulletin, 1952, 63(10), 1117-1142. http://dx.doi.
org/10.1130/0016-7606(1952)63[1117:HAAOE T]2.0.CO;2.

STRASKRABA, M. and TUNDISI, J.G. Gerenciamento da qualidade de águas de represas: diretrizes para o gerenciamento de lagos. São Carlos: ILEC, 2000.

TEIVE, L.F., LISBOA, L.K. and PETRUCIO, M.M. Uma revisão da disponibilidade de dados ecológicos visando o direcionamento de novas pesquisas na Lagoa do Peri. Revista Biotemas, 2008, 21(2), 133143.

TELES, H.F., LINARES, M.S., ROCHA, P.A. and RIBEIRO, A.S. Macroinvertebrados Bentônicos como Bioindicadores no Parque Nacional da Serra de Itabaiana, Sergipe, Brasil. Revista Brasileira de Zoociências, 1996, 321, 17-28.

THEODORO, M. and DECIAN, V.S. Mapeamento do uso da terra e fitofisionomia da bacia de captação da Corsan em Erechim, RS. AGBPA, 2014 [viewed 10 Apr. 2014]. Available from: http://www.agbpa.com. br/CD/artigos/Comunicao/planejamento\%20-\%20 PDF\%20ok/mapeamento.pdf

TREVISAN, A., HEPP, L.U. and SANTOS, S. Abundância e distribuição de Aeglidae (Crustacea: Anomura) em função do uso da terra na bacia hidrográfica do Rio Jacutinga, Rio Grande do Sul, Brasil. Zoologia, 2009, 26(3), 419-426. http://dx.doi. org/10.1590/S1984-46702009000300006.

VON SPERLING, M. Introdução a qualidade das águas no tratamento de esgoto. 3rd ed. Belo Horizonte: Departamento de Engenharia Ambiental, Universidade Federal de Minas Gerais, 2005. vol. 1.

WILHM, J.L. and DORRIS, T.C. Biological parameters for water quality criteria. Bioscience, 1968, 18(6), 477-481. http://dx.doi.org/10.2307/1294272.

Received: 06 October 2016 Accepted: 25 August 2017 